\title{
Genetic engineering of T cells with receptors from NY-ESO-1-specific tumor-recognizing CD4+ T cell as a novel approach for adoptive T cell therapy
}

\author{
Junko Matsuzaki ${ }^{*}$, Takemasa Tsuji ${ }^{1}$, Immanuel Luescher ${ }^{2}$, Hiroshi Shiku ${ }^{3}$, Junichi Mineno ${ }^{4}$, Sachiko Okamoto ${ }^{4}$, \\ Lloyd Old ${ }^{5}$, Protul Shrikant ${ }^{6}$, Sacha Gnjatic ${ }^{7}$, Kunle Odunsi ${ }^{1}$ \\ From 30th Annual Meeting and Associated Programs of the Society for Immunotherapy of Cancer (SITC 2015) \\ National Harbor, MD, USA. 4-8 November 2015
}

\section{Background}

Tumor antigen-specific $\mathrm{CD} 4^{+} \mathrm{T}$ cells generally orchestrate and regulate innate and adaptive immune cells to provide immune surveillance against malignancy. However, activation of antigen-specific $\mathrm{CD}^{+} \mathrm{T}$ cells is restricted at local tumor sites where antigen-presenting cells are frequently dysfunctional, which can cause rapid exhaustion of anti-tumor immune responses. Herein, we characterize anti-tumor effects of a unique human $\mathrm{CD} 4^{+}$ helper $\mathrm{T}$ cell subset that directly recognizes the cytoplasmic tumor antigen, NY-ESO-1, presented by MHC class II (MHC-II) on cancer cells. In addition, we clone the TCR gene from tumor-recognizing $\mathrm{CD} 4^{+} \mathrm{T}$ cells (TR-CD4) and test the function of TCR gene-engineered cells.

\section{Methods}

NY-ESO-1-specfic CD4 ${ }^{+}$or $\mathrm{CD}^{+}{ }^{+} \mathrm{T}$ cells were obtained from ovarian cancer patients who received NY-ESO-1 vaccine. Full-length TCR $\alpha$ and $\beta$ chain genes of TRCD4 were cloned by 5' RACE PCR. TCR gene was transduced into activated T cells by MSCV-based retroviral vector. The effector function was evaluated against cognate peptide-pulsed target cells or NY-ESO- $1^{+} \mathrm{MHC}-$ $\mathrm{II}^{+}$cancer cell lines by ELISA, intracellular cytokine staining or CTL assay.

\section{Results}

TR-CD4, but not conventional NY-ESO-1-specific CD4 ${ }^{+}$ $\mathrm{T}$ cells, directly recognized cancer cells in MHC-IIdependent and NY-ESO-1-specific manners. Presentation

${ }^{1}$ Roswell Park Cancer Institute, Buffalo, NY, USA

Full list of author information is available at the end of the article of intracellular NY-ESO-1 on MHC-II by cancer cells required non-classical MHC-II antigen presentation mechanisms. Upon direct recognition of cancer cells, TR-CD4 potently induced IFN- $\gamma$-dependent growth arrest in cancer cells. In addition, direct recognition of cancer cells triggers TR-CD4 to provide help to NY-ESO-1-specific CD8 ${ }^{+} \mathrm{T}$ cells by enhancing cytotoxic activity, and improving viability and proliferation. Notably, the TR-CD4 either alone or in combination with NY-ESO-1-specific CD8 ${ }^{+} \mathrm{T}$ cells significantly inhibited tumor growth in vivo in a xenograft model. Finally, retroviral gene-engineering of polyclonally activated $\mathrm{T}$ cells with TCR derived from TR-CD4 successfully produced large numbers of functional TR-CD4.

\section{Conclusions}

These observations provide mechanistic insights into the role of TR-CD4 in tumor immunity, and suggest that approaches to utilize TR-CD4 will augment anti-tumor immune responses for durable therapeutic efficacy in cancer patients. Large numbers of TR-CD4 that directly recognize cancer cells and enhance $\mathrm{CD} 8^{+} \mathrm{T}$ cell functions can be generated by gene-engineering with TCR from TR-CD4. Antigen-presenting cell-independent provision of CD4-help by TR-CD4 is especially important to enhance durable $\mathrm{CD}^{+} \mathrm{T}$ cell anti-tumor functions at the tumor local site. Adoptive T cell therapy using TR$\mathrm{CD} 4$ in combination with $\mathrm{CD} 8^{+} \mathrm{T}$ cells could be a promising strategy for effective eradication of tumors.

\section{Authors' details \\ ${ }^{1}$ Roswell Park Cancer Institute, Buffalo, NY, USA. ${ }^{2}$ Ludwig Center for Cancer Research, Epalinges, Switzerland. ${ }^{3}$ Mie University Graduate School of Medicine, Tsu, Japan. ${ }^{4}$ TAKARA BIO INC, Otsu, Japan. ${ }^{5}$ Ludwig Institute for}


Published: 4 November 2015

doi:10.1186/2051-1426-3-S2-P34

Cite this article as: Matsuzaki et al: Genetic engineering of T cells with receptors from NY-ESO-1-specific tumor-recognizing CD4+ T cell as a novel approach for adoptive T cell therapy. Journal for ImmunoTherapy of Cancer 2015 3(Suppl 2):P34.

Submit your next manuscript to BioMed Central and take full advantage of:

- Convenient online submission

- Thorough peer review

- No space constraints or color figure charges

- Immediate publication on acceptance

- Inclusion in PubMed, CAS, Scopus and Google Scholar

- Research which is freely available for redistribution

Submit your manuscript at www.biomedcentral.com/submit
() Biomed Central 